\title{
Perlindungan hukum terhadap kreditur selaku pengambil alih kredit pada kreditur
}

\author{
Febry Firmansyah.
}

Febry Firmansyah; Program Magister Ilmu Hukum Universitas Merdeka Malang; Jalan Terusan Raya Dieng No. 62-64 Malang; 65146; Jawa Timur; Indonesia.

\begin{tabular}{l} 
A R T I C L E I N F O \\
\hline Article history: \\
Received 2021-03-24 \\
Received in revised form \\
2021-07-14 \\
Accepted 2021-08-01 \\
\hline
\end{tabular}

Kata kunci:

Perlindungan Hukum; Peralihan; Kreditur.

Keywords:

Protection on the Law, Intermediate, Creditor.

DOI: https://doi.org/10.26905/

idjch.v12i2.5812.

\section{How to cite item:}

Firmansyah, F., (2021). Perlindungan hukum terhadap kreditur selaku pengambil alih kredit pada kreditur lain. Jurnal Cakrawala Hukum, 12(2), 178-186. doi:10.26905/idjch.v12i2.5812.

Corresponding Author:

* Febry Firmansyah.

E-mail address: febryfirmansyah@gmail.com.

\section{Abstrak}

Peralihan (take over) kredit adalah pembayaran yang dilakukan oleh pihak ketiga kepada kreditur, yang nantinya menggantikan kedudukannya sebagai kreditur baru terhadap debitur. Ketiadaan aturan baku mengenai pelaksanaan take over kredit mengakibatkan tidak terstandarisasinya proses pelaksanaan take over kredit. Tujaun artikel ini mengakaji perlindungan hukum para pihak dalam pelaksanaan peralihan (take over) pada Bank Jatim Cabang Banyuwangi. Jenis penelitian ini adalah penelitian hukum empiris dimana studi dilakukan di Bank Jatim Cabang Banyuwangi. Hasil penelitianyang dilakukan oleh Notaris/PPAT di Banyuwangi termasuk dalam kategori subrogasi dengan cara undang-undang (Pasal 1403 KUH Perdata). Dalam pelaksanaan take overkredit perlindungandiperoleh melalui penandatanganan kembali SKMHT pada saat Surat Roya, dan sertifikat bukti kepemilikan jaminan telah dikeluarkan secara fisik oleh kreditur awal. Pelaksanaan peralihan (take over) untuk kreditur baru pada Bank Jatim Cabang Banyuwangi diperoleh melalui penandatanganan kembali SKMHT yang merupakan dasar pembuatan APHT pada saat surat roya, bukti pelunasan kredit, dan sertifikat bukti kepemilikan jaminan telah dikeluarkan secara fisik oleh kreditur (bank) awal. Pengecekan awal sebelum sertifikat bukti kepemilikan dikeluarkan oleh kreditur awal dilakukan dengan cara menerbitkan Surat Keterangan Pendaftaran Tanah (SKPT) melalui BPN.

\section{Abstract}

Credit take over is a payment made by a third party to a creditor, who will replace his position as a new creditor to the debtor. The absence of standard rules regarding the implementation of credit take over has resulted in non-standardization of the credit take over implementation process. The purpose of this article is to examine the legal protection of the parties in implementing the take over at Bank Jatim 
Banyuwangi Branch. This type of research is empirical legal research where the study was conducted at Bank Jatim Banyuwangi Branch. The results of research conducted by a Notary/PPAT in Banyuwangi are included in the category of subrogation by way of law (Article 1403 of the Civil Code). In the implementation of take over credit protection is obtained through the re-signing of the SKMHT at the time of the Roya Letter, and a certificate of proof of ownership of the guarantee has been physically issued by the initial creditor. The implementation of the take over for new creditors at Bank Jatim Banyuwangi Branch is obtained through the re-signing of the SKMHT which is the basis for making APHT when the roya letter, proof of credit repayment, and certificate of proof of collateral ownership have been physically issued by the initial creditor (bank). The initial check before the certificate of proof of ownership is issued by the initial creditor is carried out by issuing a Land Registration Certificate (SKPT) through the BPN.

\section{Latar Belakang}

Bank sebagai badan usaha berperan menghimpun dan menyalurkan dana dari dan ke masyarakat dalam menjalankan usahanya bank harus selalu memegang teguh prinsip kehati-hatian, hal ini sesuai dengan prinsip "prudential banking". Normalnya, dalam penyaluran kredit yang aman, selain terdapat jaminan utama, bank juga mensyaratkan adanya jaminan tambahan berupa benda yang memiliki nilai ekonomis. Jaminan tambahan itu menjadi begitu diperlukan, karena dengan adanya jaminan tambahan tersebut bank jadi merasa lebih secure dalam menyalurkan kreditnya. Jaminan tambahan dapat meningkatkan kepercayaan kreditur terhadap debiturnya, terjaminnya pembayaran kembali kredit yang telah disalurkan.

Salah satu fasilitas dalam pemberian pinjaman yang biasa ditawarkan oleh dunia perbankan yakni lewat peralihan kredit (take over). Pengambilalihan (take over) kredit ialah peristiwa hukum yang terjadi bila pihak ketiga (kreditur baru) melunasi hutang debitur pada kreditur lama dengan tujuan untuk mengambil alih peran kreditur lama, dengan metode pihak ketiga (kreditur baru) memberikan kredit dengan skema kredit tertentu pada debitur yang dipakai untuk melunasi sisa pinjaman (outstanding) yang tadinya telah diperoleh oleh debitur dari kreditur lama dengan perjanjian kredit tertentu, sehingga posisi kreditur lama digantikan oleh pihak ketiga itu (selaku kreditur baru). Untuk memberikan perlindungan baik untuk pihak debitur ataupun kreditur, dalam pelaksanaannya diperlukan sesuatu alat bukti tertulis yang bersifat autentik yang dibuat dihadapan pejabat yang berwenang seperti Notaris atau PPAT, yang diatur dalam ketentuan Pasal 1868 Kitab Undang-Undang Hukum Perdata.

Dalam praktiknya peralihan kredit atau take over dalam perbankan diawali dari pengajuan permohonan pinjaman, setelah itu penyerahan seluruh kelengkapan dokumen yang diperlukan serta syaratsyarat pengajuan kredit yang lain. Kemudian Pihak Bank melakukan survey oleh Analis Kredit, dilakukannya verifikasi dilapangan perihal jaminan tambahan, usaha calon debitur, SLIK, serta beberapa analisa penunjang lainnya seperti anlisis $5 \mathrm{C}$. Bila telah memenuhi ketentuan maka dilanjutkan dengan pembuatan proposal pinjaman. Akad kredit kemudian dilakukan apabila proposal pinjaman telah disetujui oleh komite pemutus kredit yaitu dengan dilakukannya penandatanganan di Notaris/PPAT antara debitur dengan pasangannya, serta kreditur.

Setelah melaksanakan perjanjian dan serta pengikatan jaminan tambahan, berikutnya debitur dengan didampingi oleh Analis Kredit menuju ke 
kreditur semula (bank semula) untuk melaksanakan pelunasan dengan dana yang telah diperoleh dari pihak ketiga (kreditur baru). Bila pelunasan telah dilakukan sampai berkas tanda pelunasan dan bukti asli kepemilikan jaminan diperoleh, maka dapat dibebani Hak Tanggungan terhadap jaminan tambahan (benda tidak bergerak/tanah) dengan terlebih dahulu dilakukan roya (pencoretan hak) terhadap hak tanggungan atas nama kreditur di bank sebelumnya (kreditur awal).

Permasalahan yang dapat timbul adalah ketika dilakukan penandatanganan akad kredit dan pengikatan jaminan Surat Kuasa Membebankan Hak Tanggungan (SKMHT) sebelum surat roya dipastikan terbit pada hari yang sama. Hal ini dilakukan untuk memberikan kepastian hukum. Di dalam akta SKMHT dan akta APHT terdapat janjijanji dan apabila Notaris menggunakan SKMHT sebelum tanggal surat roya dipastikan terbit pada hari yang sama, terjadi pembebanan ulang Hak Tanggungan. Padahal dalam Akta Pembebanan Hak Tanggungan terdapat janji dan ketentuan dalam perjanjian kredit sebelumnya, dilarang mengalihkan obyek jaminan sebelum kredit dinyatakan lunas oleh kreditur. Surat roya merupakan salah satu bukti pernyataan tertulis kreditur yang menyatakan bahwa hutang debitur pada kreditur telah lunas dan berdasarkan surat roya tersebut dimintakan kepada badan pertanahan (BPN) untuk melakukan pencoretan/penghapusan hak tanggungan.

Bila pejabat menggunakan SKMHT sebagai suatu instrumen peralihan kredit tanpa surat roya keluar dihari itu juga, berarti pemilik sertipikat memberikan kuasa kembali pada kreditur (bank) yang baru yang hendak mengklaim (untuk disebut penerima kuasa). Akhirnya, akta yang dibuat oleh pejabat atau PPAT bisa menjadi cacat hukum. (Muladi, 2020), Waktu penandatanganan SKMHT dan Akta Pembebanan Hak Tanggungan (APHT), seyogyannya pejabat atau PPAT memiliki keyakinan bahwa pemberi Hak Tanggungan memiliki kewenangan untuk melakukan perbuatan hukum terhadap obyek Hak Tanggungan yang akan dibebani, walaupun kepastian mengenai dimilikinya kewenangan tersebut baru dipersyaratkan pada saat pemberian Hak Tanggungan itu didaftarkan. (Sjahdeini, 1999) Penandatanganan akta SKMHT pada dasarnya menurut Undang-Undang Nomor 4 Tahun 1996 (UUHT) adalah telah termasuk sebagai salah satu langkah dalam proses pembebanan hak tanggungan.

Hal itu dapat dilihat pada Pasal 11 ayat (2) butir g Undang-Undang Hak Tanggungan Nomor 4 Tahun 1996, "terdapat janji-janji antara lain yaitu janji bahwa pemberi Hak Tanggungan tidak akan melepaskan haknya atas objek Hak Tanggungan tanpa persetujuan tertulis lebih dahulu dari Pemegang Hak Tanggungan", yang mana bukti tertulis tersebut berupa surat bukti pelunasan hutang dan surat roya. Sahnya pemberi Hak Tangungan untuk menguasakan pembebanan Hak Tanggunagan apabila sudah ada surat roya dari pemegang Hak Tanggungan, selanjutnya dikeluarkannya sertifikat, dan akte pengikatan jaminan. Sesuai dengan ketentuan salah satu syarat sahnya suatu perjanjian didalam Pasal 1320 KUH Perdata.

Berdasarkan uraian diatas maka paper ini mengkaji pelaksanaan pembebanan jaminan benda tanah dalam proses peralihan (take over) kredit pada Bank Jatim Cabang Banyuwangi dan perlindungan hukum terhadap pihak yang mengambil alih kredit (Bank Jatim Cabang Banyuwangi) dalam pelaksanaan peralihan (take over) kredit pada Bank lain (kreditur awal).

\section{Metode}

Metode Penelitian dalam penulisan artikel ini adalah metode penelitian hukum empiris. Metode penelitian dengan melakukan Pengumpulan data dilapangan menggunakan kuisioner yang bersifat tertutup dan terbuka. Sehingga sebagai data primernya adalah hasil kuisioner yang bersifat tertutup dan terbuka, Data primer yang telah dikumpulkan hasil kuisioner tersebut kemudian 
dianalisis secara kualitatif, kemudian disajikan secara deskriptif analitis preskriptif serta teknik penarikan kesimpulan dilakukan secara Induktif.

\section{Pembahasan}

Menurut pemikiran Hans Kelsen yang mendasar adalah sikapnya terhadap persolan hukum "is' (yang ada) dan hukum yang ought" (yang seharusnya ada). Dalam ajaran suatu peraturan yang sifatnya tertulis mengandung pernyataan yang "seharusnya" (das sollen) dilakukan baik oleh masyarakat maupun para pihak sehingga akan terwujud kepastian hukum. (Marzuki, 2008)

Seperti yang dikonsepkan oleh Gustaf Radbruch terkait hukum yang ditopang oleh tiga nilai dasar yaiut keadilan, kemanfaatan dan kepastian. Keadilan merupakan hal yang utama dari ketiga hal itu tetapi tidak berarti dua unsur yang lain dapat dengan serta merta diabaikan kepastian hukum dimaknai dengan kondisi dimana hukum dapat berfungsi sebagai peraturan yang harus ditaati". (Hujibers, 2016)

Menurut Philipus M. Hadjon mengemukakan ada 2 jenis perlindungan hukum yaitu pertama perlindungan hukum preventif yang bertujuan mencegah terjadinya sengketa. Kedua, perlindungan hukum represif yang bertujuan untuk menyelesaikan sengketa. Selanjutnya Moch. Isnaeni menjelaskan konsep perlindungan hukum internal dan eksternal. perlindungan hukum internal dapat dibuat oleh para pihak melalui perjanjian sehingga berlaku hanya bagi para pihak. Sedangkan yang eksternal berasal dari pemerintah yang berbentuk peraturan yang berlaku untuk masyarakat. (Isnaeni, 2016)

\section{Konsep Peralihan (take over) Kredit Secara Umum, dan Konsep Subrogasi dalam KUH Perdata}

Dalam dunia bisnis perbankan, peralihan (take over) kredit merupakan suatu istilah yang di- pakai dalam hal pihak ketiga memberikan kredit kepada debitur yang bertujuan untuk melunasi hutang debitur kepada kreditur awal dan memberikan kredit baru kepada debitur sehingga kedudukan pihak ketiga ini menggantikan kedudukan kreditur awal. Peristiwa peralihan (take over) kredit dalam Kitab Undang-Undang Hukum Perdata dikenal dengan sebutan "subrogasi". Dalam KUHPerdata Pasal 1400, definisi subrogasi yaitu "perpindahan hak kreditur kepada kepada seorang pihak ketiga yang membayar kepada kreditur, dapat terjadi karena persetujuan atau karena undang-undang".

Pada Pasal 1401 terjadinya subrogasi dapat melalui persetujuan (secara langsung) dan berdasarkan peraturan perundang-undangan (secara tidak langsung). Dalam praktiknya, metode peralihan kredit atau take over diawali dari permohonan pinjaman, diikuti dengan penyerahan seluruh kelengkapan data sebagai kewajiban pengajuan kredit yang lain. Kemudian dilakukannya peninjauan oleh Analis Kredit, kemudian verifikasi dilapangan perihal jaminan tambahan, usaha calon debitur, SLIK, serta beberapa analisa penunjang lainnya seperti anlisis $5 \mathrm{C}$. Bila telah memenuhi ketentuan hingga dilanjutkan dengan pembuatan proposal kredit yang diajukan pada komite pemutus kredit. Akad kredit dilakukan apabila proposal kredit telah disetujui oleh komite pemutus kredit yaitu dengan dilakukannya penandatanganan di Notaris/ PPAT antara debitur dengan pasangannya, serta kreditur.

Setelah melaksanakan akad kredit serta pengikatan jaminan tambahan, berikutnya debitur dengan didampingi oleh Analis Kredit menuju ke kreditur semula (bank semula) untuk melaksanakan pelunasan dengan dana yang telah diperoleh dari pihak ketiga (kreditur baru). Bila pelunasan telah dilakukan, hingga mendapatkan berkas tanda pelunasan dan asli bukti kepemilikan jaminan, untuk berikutnya dapat dibebani Hak Tanggungan terhadap jaminan tambahan (benda tidak bergerak/ tanah) dengan terlebih dulu dilakukan roya (penco- 
retan hak) terhadap hak tanggungan atas nama kreditur di bank sebelumnya (kreditur awal).

Menurut ketentuan Pasal 1 dan 17 Undang Undang Hak Tanggungan (UUTH) Peralihan Hak Tanggungan dapat dilakukan dengan beberapa cara, yaitu: a) Cessie, yaitu perbuatan hukum yang mengalihkan piutang oleh kreditur pemegang Hak Tanggungan pada pihak lainnya. Cessie harus dilakukan dengan akta autentik dan akta bawah tangan; b) Subrogasi, yaitu penggantian kreditur oleh pihak ketiga yang melunasi utang debitur. Terdapat 2 (dua) cara terjadinya subrogasi, yaitu karena: (a) perjanjian (kontraktual); dan (b) undangundang.

Pasal 16 Undang-Undang Nomor 4 Tahun 1996 tentang Hak Tanggungan diatur bahwa pengalihan kredit dengan cara subrogasi mengalihkan juga hak dan wewenang kreditur lama kepada kreditur baru. Pengalihan terjadi pula terhadap jaminan Hak Tanggungan yang berkaitan dengan perjanjian kredit yang menimbulkan kredit yang dialihkan.

Berdasarkan wawancara yang dilakukan kepada beberapa Notaris/PPAT di wilayah Banyuwangi. (Notaris/PPAT, 2020), dalam melakukan take over terdapat beberapa tahapan prosedur yang akan dijabarkan sebagai berikut: 1). Dilakukan pengecekan "cek intip" terlebih dahulu, atau dapat juga dimohonkan kepada BPN untuk dapat diterbitkannya Surat Keterangan Pendaftaran Tanah (SKPT); 2) Pihak bank yang baru sebaiknya memastikan terlebih dahulu kondisi obyek jaminan di bank sebelumnya apakah obyek jaminan tersebut pengikatannya dilakukan secara paripasu atau tidak, peringkat hak tanggungannya juga harus dipastikan merupakan hak tanggungan peringkat keberapa, juga sebaiknya sertifikat bukti kepemilikan dari obyek jaminan yang akan di take over sudah ditunjukan fisiknya sehingga terhindar dari risiko kehilangan sertifikat; 3) Pihak bank yang baru juga harus memastikan bahwa bank awal yang akan di take over bersedia mengeluarkan tanggal surat roya yang minimal sama dengan tanggal SKMHT; 4) Apabila pihak bank awal mempersulit dalam proses take over ini engan berbagai alasan, maka dapat dilakukan alternatif untuk menandatangani dua SKMHT sekaligus, yang salah satu SKMHT nya di tanggali pada saat surat roya dari bank awal benar-benar telah dikeluarkan, namun hal ini sangat berisiko apabila terdapat masalah hukum dan debitur dapat membuktikan bahwa pada tanggal tersebut yang bersangkutan sedang berada diluar kota sehingga tidak mungkin untuk melakukan tanda tangan, hal ini berisiko terhadap SKMHT tersebut, yaitu dapat dibatalkan/ batal demi hukum; 5) Kondisi yang paling ideal adalah debitur dipanggil lagi untuk dilakukannya penandatanganan kembali terhadap SKMHT tersebut ketika surat roya dan sertifikat bukti kepemilikan asli telah dikeluarkan oleh bank sebelumnya;

Ketiga Notaris/PPAT di wilayah Banyuwangi tersebut, dalam melaksanakan praktik take over kredit, penulis menyimpulkan bahwa ketiga Notaris/PPAT tersebut telah memiliki keseragaman dalam hal pelaksanaan pembebanan jaminan benda tanah dalam proses peralihan (take over) kredit pada Bank Jatim Cabang Banyuwangi. Praktik pelaksanaan proses take over dari ketiga Notaris/ PPAT tersebut sudah tepat, karena memanglah benar bahwa Hak Tanggungan terlahir pada saat APHT didaftarkan di kantor pertanahan. Namun menurut penulis, sebenarnya SKMHT juga sudah masuk kedalam tahap pemberian HT. Hal ini didasarkan pada ketentuan yang mengatur mengenai cara pemberian HT diatur dalam Pasal 10 dan Pasal 15 UUHT yang menyatakan ada 2 (dua) cara pemberian HT, yaitu tata cara pemberian HT oleh pemberi HT secara langsung (dengan APHT), dan dalam Pasal 15 UUHT diatur tentang pemberian kuasa pembebanan HT oleh pemberi HT kepada penerima kuasa (melalui SKMHT). Sehingga pada tahap SKMHT kewenangan pemberi HT harus sudah jelas dan sangat mempengaruhi keabsahan lahirnya APHT yg didasarkan oleh SKMHT 
tersebut bila dikaitkan dengan syarat sahnya perjanjian pada Pasal 1320 KUH Perdata.

Para Notaris/PPAT di wilayah Banyuwangi tersebut rata-rata untuk menyikapi proses peralihan kredit tersebut, dilakukan penandatanganan kembali terhadap SKMHT yang menemui kendala surat roya, bukti lunas, dan sertifikat bukti kepemilikan tidak dapat keluar pada hari yang sama dengan penandatanganan SKMHT, yang menjadi dasar dibuatnya APHT dan pada akhirnya menjadi SHT yang dikeluarkan oleh BPN. Hal tersebut untuk menghindari risiko terjadinya pembebanan ulang terhadap obyek jaminan yang masih menjadi jaminan pada kreditur lain yang dikarenakan belum dapat dikeluarkannya surat roya maupun bukti lunas pada kreditur awal (bank). Dengan demikian maka sudah tepat langkah yang diambil oleh Notaris/PPAT di wilayah Banyuwangi yaitu melakukan penandatanganan ulang SKMHT ketika surat roya, bukti pelunasan, dan sertifikat bukti kepemilikan yang asli telah dikeluarkan oleh kreditur awal (bank).

Berkaitan dengan proses pengecekan tidak dilakukannya secara fisik terhadap sertifikat bukti kepemilikan jaminan kebendaan. Menurut wawancara dengan salah satu Notaris/PPAT di Banyuwangi yang menjadi responden dalam penelitian ini (Notaris/PPAT, 2020), dalam SKMHT pengecekan tidak diperlukan pengecekan fisik sertifikat kepemilikan aslinya, dan untuk itu dapat digantikan dengan menerbitkan Surat Keterangan Pendaftaran Tanah (SKPT) di BPN. Berdasarkan kebiasaan yang selama ini ada dalam pengurusan HT di BPN Banyuwangi, hal tersebut tidak menjadi masalah, dibuktikan dengan dapat diterbitkannya Sertifikat Hak Tanggungan (SHT) oleh Kantor Pertanahan (BPN) Banyuwangi.

Dari analisis proses take over yang telah dijabarkan diatas dapat dilihat bahwa pelaksanaan pembebanan jaminan benda tanah dalam proses peralihan kredit (take over) pada Bank Jatim Cabang Banyuwangi telah memiliki keabsahan secara hukum. Pelaksanaan pembebanan hak tanggungan yang diawali dengan penggunaan lembaga SKMHT yang menjadi dasar dalam pembuatan APHT. Namun proses pelaksanaannya dapat dikatakan masih belum efektif dan masih terdapat potensi risiko-risiko hukum bagi kreditur baru yang melakukan pengambilalihan kredit pada kreditur awal. Tidak adanya aturan baku mengenai pelaksanaan peralihan (take over) kredit mengakibatkan tidak terstandarisasinya proses pelaksanaan take over tersebut.

Persaingan yang ketat dalam dunia perbankan menambah sulitnya kontrol terhadap praktek-praktek yang kurang sehat apabila debitur ingin mengalihkan kreditnya dari satu bank ke bank lain. Padahal secara asas, debitur bebas melakukan perikatan dengan siapapun yang ia kehendaki, hal ini sejalan dengan suatu asas yaitu asas kebebasan berkontrak. Agar perlindungan hukum terhadap kreditur baru selaku pengambil alih (take over) kredit pada kreditur awal dapat terpenuhi. Pihak pengawas perbankan yaitu Otoritas Jasa Keuangan (OJK) sebaiknya membuat suatu aturan pelaksana mengenai peralihan (take over) kredit dilapangan yang terstandarisasi, yang dapat memaksa dan mewajibkan khususnya kreditur awal sebagai pihak yang di take over. Hal itu untuk tidak menghambat proses pelunasan, penerbitan surat roya pada hari pelunasan, dan pengeluaran sertifikat bukti kepemilikan obyek jaminan.

Setelah aturan pelaksana dalam proses peralihan (take over) kredit ditertibkan dan terstandarisasi (oleh OJK), maka peralihan sebaiknya dilakukan sesuai dengan ketentuan Pasal 16 Undang-Undang Nomor 4 Tahun 1996 tentang Hak Tanggungan. Dengan menggunakan lembaga subrogasi (subrogasi dengan cara perjanjian), yang secara otomatis dialihkannnya hak dan wewenang ke kreditur baru. Termasuk juga terhadap jaminan Hak Tanggungan yang berkaitan dengan perjanjian kredit tersebut. 
Hal ini akan membuat peralihan (take over) kredit dalam dunia perbankan khususnya di Banyuwangi dapat lebih tertata, tertib, sederhana, memiliki kepastian dan perlindungan hukum dalam pelaksanaannya. Hal ini sejalan dengan teori perlindungan hukum menurut Moch. Isnaeni, bahwa berdasarkan sumbernya perlindungan hukum dibagi menjadi dua yaitu: Perlindungan hukum internal yang keberadaannya dibuat sendiri oleh para pihak lewat media perjanjian dan Perlindungan hukum eksternal yang eksistensinya berasal dari penguasa lewat aturan perundangundangan.

Sejalan dengan teori perlindungan hukum menurut Phillipus M. Hadjon, Perlindungan hukum preventif artinya rakyat diberi kesempatan menyatakan pendapatnya sebelum keputusan pemerintah mendapat bentuk yang definitive yang bertujuan untuk mencegah terjadinya sengketa; dan Perlindungan hukum represif yang bertujuan untuk menyelesaikan sengketa.

\section{Simpulan}

Proses pelaksanaan peralihan (take over) kredit pada Bank Jatim Cabang Banyuwangi telah memiliki kepastian hukum, dalam hal ini yaitu keabsahan pelaksanaan pembebanan hak tanggungan yang diawali dengan penggunaan lembaga SKMHT yang menjadi dasar dalam pembuatan APHT. Pelaksanaan pembebanan jaminan benda tanah pada Bank Jatim Cabang Banyuwangi telah dilakukan sesuai dengan aturan yang berlaku, yaitu apabila dikaitkan dalam konteks subrogasi dalam KUH Perdata, maka subrogasi yang dilakukan oleh Notaris/PPAT di Banyuwangi adalah masuk dalam kategori subrogasi dengan cara Undangundang (Pasal 1403 KUH Perdata).

Pelaksanaan take over ini dapat dikatakan masih belum efektif dan cukup rumit serta masih terdapat potensi risiko-risiko hukum bagi kreditur baru yang melakukan pengambilalihan kredit pada kreditur awal, yang dapat mengakibatkan terde- gradasinya kreditur baru yang seharusnya merupakan kreditur preferen menjadi kreditur konkuren karena kurang sempurnanya proses pengikatan jaminan dalam proses peralihan (take over) kredit. Pengecekan awal sebelum sertifikat bukti kepemilikan dapat ditunjukan secara fisik dapat dilakukan dengan cara menerbitkan Surat Keterangan Pendaftaran Tanah (SKPT) melalui BPN.

\section{Daftar pustaka}

Ali, Achmad. 2017. Menguak Tabir Hukum. Jakarta: Kencana.

Amalia, Nanda. 2013. Hukum Perikatan. Aceh: Unimal Press.

Andrianto, Didin Fatihuddin, Anang Firmansyah. 2019. Manajemen Bank. Surabaya: Penerbit Qiara Media.

Budiono, Herlien. 2014. Ajaran Umum Hukum Perjanjian dan Penerapannya DiBidang Kenotariatan. Bandung: Citra Aditya Bakti.

Fuady, Munir. 2013. Teori-teori besar (Grand Theory) Dalam Hukum. Jakarta: Kencana.

HS, H. Salim. 2004. Perkembangan Hukum Jaminan Indonesia. Jakarta: Raja grafindo Persada.

http:/ / hukumperbankan.blogspot.com/2008/12/ prinsip-prinsip-dasar-agunan-atau.html, PrinsipPrinsip Dasar Agunan atau Jaminan. Hukum dan Perbankan Online.

http://tesishukum.com. Pengertian Perlindungan Hukum Menurut Para Ahli.

https:/ /idlegal.id/asas-asas-hukum-perjanjian-dalamkuh-perdata/.Asas-Asas Hukum Perjanjian Dalam KUH Perdata. ID Legal.

Hujibers, Theo. 2016. dalam R. Tony Prayogo. Penerapan Asas Kepastian Hukum Dalam Peraturan Mahkamah Agung Nomor 1 Tahun 2011 Tentang Hak Uji MAteriil dan Dalam Peraturan Mahkamah Konstitusi Nomor 06/PMK/2005 Tentang Pedoman Beracara Dalam Pengujian Undang-Undang. Jurnal Legislasi Indonesia, Vol. 13 No. 02 .

Isnaeni, Moch. 2006. Hipotek Pesawat Udara di Indonesia. Surabaya: Dharma Muda. 
Isnaeni, Moch. 2016. Pengantar Hukum Jaminan Kebendaan. Yogyakarta: Laksbang Pressindo.

Isnaeni, Moch. 2017. Pengantar Hukum Jaminan Kebendaan. Yogyakarta: Laksbang Pressindo.

Justitia, Widya, Zil Aidi. 2017. Perlindungan Hukum Terhadap Bank Sebagai Kreditur Baru Dalam Pengalihan Piutang Atas Kredit Pemilikan Rumah Secara Top Up. Yogyakarta: Jurnal Yuridis Vol. 4 No. 2, Program Pasca Sarjana Fakultas Hukum Universitas Gadjah Mada.

Kie, Tan Thong. 2002. Studi Notariat dan Serba-serbi PraktekNotaris. Jakarta: Ichtiar Baru Van Hoeve.

Kitab Undang-Undang Hukum Perdata (KUHPer).

Liestiyowati. Definisi dan Mekanisme Take Over (Subrogasi) dalam Dunia Perbankan. http://akuntansi.blogspot.com/2013/09/definisi-danmekanisme-takeover.html

Liestiyowati. Definisi dan Mekanisme Take Over (Subrogasi) dalam Dunia Perbankan. http://akuntansi.blogspot.com/2013/09/definisi-danmekanisme-takeover.html.

Marzuki, Peter Mahmud. 2008. Pengantar Ilmu Hukum. Jakarta: Kencana.

Mertokusumo, Sudikno. Eksekusi Obyek Hak Tanggungan (Permasalahan dan Hambatan). Yogyakarta. Makalah pada Penataran Dosen Hukum Perdata Se-Indonesia. Fakultas Hukum Universitas Gajah Mada

Muchsin. 2003. Perlindangan dan Kepastian Hukum bagi Investor di Indonesia. Surakarta: Disertasi Magister Ilmu Hukum Program Pasca Sarjana Universitas Sebelas Maret.

Muhamad, Abdul Kadir. 1991. Hukum Perdata Indonesia. Bandung: Citra Aditya Bakti.

Muhamad, Abdul Kadir. 1992. Hukum Perikatan. Bandung: Citra Aditya.

Muladi, Liezty Sabrina. Hati-hati Terhadap Penggunaan $S K M H T$, Ikatan Notaris Indonesia Wilayah Sumsel. http:// pengwilinisumsel.blogspot.com/ 2013/09/hati-hati-terhadap penggunaan-skmht.

Mulyono, G. P., \& Fatoni, R. (2020). Demokrasi Sebagai Wujud Nilai-nilai Sila Keempat Pancasila dalam Pemilihan Umum Daerah di Indonesia. Citizenship Jurnal Pancasila dan Kewarganegaraan, 7(2), 97107.
Peraturan Pemerintah Nomor 24 Tahun 1997 tentang Pendaftaran Tanah.

Peraturan Pemerintah Nomor 24 Tahun 2016 tentang Perubahan Atas Peraturan Pemerintah Nomor 37 Tahun 1998 Tentang Peraturan Jabatan Pejabat Pembuat Akta Tanah.

Prasetyawati, Niken. 2015. Jaminan Kebendaan dan Jaminan Perorangan Sebagai Upaya Perlindungan Hukum Bagi Pemilik Piutang. Surabaya. Jurnal Sosial Humaniora, Vol 8 No. 1 ITS.

Prodjodikoro, Wirjono. 1986. Asas-Asas Hukum Perjanjian. Bandung: Bale.

Rahardjo, Satjipto. 1993. Penyelenggaraan Keadilan Dalam Masyarakat Yang Sedang Berubah. Jurnal Masalah Hukum. Edisi 10.

Rato, Dosminikus. 2010. Filasafat Hukum Mencari dan Memahami Hukum. Bandung: Presindo.

Satrio, J. 1984. Hak-Hak Jaminan Kebendaan. Bandung: Citra Aditya Bakti.

Setiawan, Dadang Agus. 2018. Keabsahan Surat Kuasa Membebankan Hak Tanggungan Dalam Proses Peralihan Kredit Antar Bank. Jurnal Hukum dan Kenotariatan. E-Jurnal Unisma, Volume 2 Nomor 2.

Sidarta, Arief. 1996. Refleksi Tentang Hukum. Bandung: Citra Aditya Bakti.

Sjahdeini, Remy. 1999. Hak Tanggungan Asas-asas Ketentuan-ketentuan Pokok dan Masalah yang Dihadapi oleh Perbankan. Bandung: Penerbit Alumni.

Soekamto, Soerjono. 2015. Pengantar Penelitian Hukum. Jakarta: UI-Press.

Subekti. 1987. Pokok-Pokok Hukum Perdata. Jakarta: Internusa.

Sugiyono. 2020. Metode Penelitian Kualitatif. Bandung: Alfabet.

Suharnoko. 2012. Doktrin Subrogasi, Novasi, dan Cessie. Jakarta: Kencana Prenada Media.

Sutarno. 2003. Aspek-Aspek Hukum Perkreditan Pada Bank. Bandung: Alfabeta.

Sutedi, Adrian. 2012. Hukum Hak Tanggungan. Jakarta: Sinar Grafika. 


\section{Jurnal Cakrawala Hukum, Volume 12 No. 2 Agustus 2021}

ISSN PRINT 2356-4962 ISSN ONLINE 2598-6538

Tim Pengajar Diklat Kemahiran Hukum Kontrak. 2005. Buku Ajar Diklat Kemahiran Hukum Kontrak. Padang: Universitas Andalas.

Tobing, Rudyanti Dorotea. 2014. Hukum Perjanjian Kredit (Konsep Perjanjian Kredit Sindikasi yang Berasaskan Demokrasi Ekonomi). Yogyakarta: Laksbang Grafika.

Toha, Syarief. 2017. Problematika Dalam Pelaksanaan Pengambilalihan Kredit dengan Jaminan Hak Tanggungan. Jurnal UNS, Vol 4, No 2.

Undang-Undang Nomor 10 Tahun 1998 tentang perubahan atas Undang-Undang Nomor 7 Tahun 1992 Tentang Perbankan.
Undang-Undang Nomor 2 Tahun 2014 tentang Perubahan Atas Undang-Undang Nomor 30 Tahun 2004 Tentang Jabatan Notaris (UUJN-P).

Undang-Undang Nomor 37 Tahun 2004 tentang Kepailitan dan Penundaan Kewajiban Pembayaran Utang.

Undang-Undang Nomor 4 Tahun 1996 tentang Hak Tanggungan atas Tanah Beserta Benda-Benda yang Berkaitan dengan Tanah.

Undang-Undang Nomor 5 Tahun 1960 tentang Peraturan Dasar Pokok-Pokok Agraria. 